\title{
Austrian development policy - from global to neighbourhood policy?
}

\author{
Simon Lightfoot', Michael Obrovsky ${ }^{2, *}$ \\ 1 School of Politics and International Studies, University of Leeds, UK \\ 2 Österreichische Forschungsstiftung für Internationale Entwicklung, Wien, Österreich \\ * E-Mail: m.obrovsky@oefse.at
}

\begin{abstract}
When Austria joined the EU in 1995, it was expected that the Austrian government would increase the Official Development Assistance (ODA) budget and organise their aid management more in line with European and international standards. There was thus an expectation that Austria would witness a Europeanization of its development policy. Looking at the situation after 20 years of membership, it seems that Austria took on board the European development rhetoric without a significant increase of the overall ODA budget. Although a more professional Austrian Development Agency (ADA) has been established, ODA is still focused more on neighbourhood policy in the Western Balkans and in promoting foreign trade interests in the Caucasus region than on poverty reduction in the global south and in delivering contributions to the global public goods. Due to the lack of a strong binding acquis, Austria has been able to hide under the umbrella of an European Development policy with development rhetoric and some adjustment of implementing structures without any significant financial disbursements.
\end{abstract}

\section{Keywords}

Austria, development policy, development co-operation, neighbourhood Policy, ODA, Europeanization

\section{Österreichische Entwicklungspolitik - Nachbarschaftspolitik in Europa statt globaler Politik?}

\section{Zusammenfassung}

Mit dem Beitritt Österreichs zur EU im Jahr I995 wurde erwartet, dass Österreich die öffentliche Entwicklungshilfe (ODA) auf ein europäisches Niveau anheben und sein EZA Management professionalisieren und mehr in Einklang mit europäischen und internationalen Standards bringen wird müssen. Nach 20 Jahren EU Mitgliedschaft lässt sich resümieren, dass Österreich zwar die europäische Entwicklungsrhetorik übernommen hat, jedoch seine öffentlichen Entwicklungshilfemittel nicht angehoben hat. Trotz der Gründung einer professionellen Österreichische Entwicklungsagentur (ADA) ist die ODA stärker auf Nachbarschaftspolitik im westlichen Balkan sowie auf die Stärkung der österreichischen Wirtschaftsinteressen im Kaukasus ausgerichtet als auf die Armutsbekämpfung im globalen Süden sowie Beiträge zu den globalen öffentlichen Gütern. Da verbindliche Verträge über die ODA-Leistungen der EU-Mitglieder fehlen, konnte sich Österreich mit Entwicklungsrhetorik und effizienteren Managementstrukturen hinter der EU-Entwicklungspolitik verstecken ohne die ODA-Mittel signifikant zu erhöhen.

\section{Schlüsselwörter}

Österreich, Europäisierung, EU Außenpolitik, Regionale Kooperation, Forum Salzburg, Zentraleuropäische Verteidigungskooperation

The authors have declared that no competing interests exist. 


\section{Introduction}

This paper examines the nature of Austrian development policy since accession to the EU in 1995 . We identify a visible paradox; that despite a common political acceptance of the $0,7 \%$ goal amongst all mainstream Austrian political parties, development policy has been a more than 'decadelong political irrelevance'. This traditional contradiction between rhetoric and policy reality requires us to raise the questions: Why is this so? Is there a stronger obligation for Austria to close the gap due to EU membership? We are therefore interested in the politics behind these decision as we have evidence from Switzerland and the UK that even in the middle of the recent economic crisis, ODA levels can increase if there is political will.

Looking at foreign policy and national interests in Austria alongside the legal framework of the EU, we examine the political economy of Austrian development policy. Using a framework of Europeanization, we explore whether Austria's strategic foreign policy interests in the Western Balkans and the Eastern Neighbourhood have changed Austrian development policy from a more global perspective to a more neighbourhood perspective, thereby becoming less aligned with European development policy. It examines specific issues such as burden sharing in financing for development, following international development goals, specific Austrian economic interests in the partner countries and security and peace interests before looking at the Austrian contribution to policy initiatives at the EU level. The paper examines to what extent Austria has been able to influence the EU agenda in the field of development policy and the EU's top-down influence on Austria's national foreign policy by examining Austria's actions in 3 key aspects of development policy. The article also looks at the extent to which Austria is able to forge alliances (both ad hoc as well as through more durable partnerships), prioritization of objectives and resources, and drawing on EU resources. The overall argument examines the added value of the Austrian foreign and development policy to the EU, with a specific focus on the Western Balkans and to a certain extent to the Caucasus. The paper argues as well that the shift from a more global perspective to a neighbourhood perspective follows the Austrian and the European interests. Whilst this might be in line with donor states attempting to carve a niche for themselves in development policy, it does run counter to the spirit of the EU acquis in this field.

\section{Background}

Twenty years after the accession of Austria to the EU it is worth looking to see to what extent Austrian development policy and development cooperation had changed. In particular, we are interested whether there are substantial efforts and whether they can be explained by the accession to the EU and policy alignment with the acquis or are they more closely aligned to activities which are of interest to Austrian Foreign Policy?

International aid policy was an integrated part of the Austrian foreign policy during the government of Bruno Kreisky between 1970 and 1983 in order to position Austria as a neutral country, which was able to promote and support the interests of developing countries at the UN level (Obrovsky 1993). Prior to accession the policy was characterised as an ambitious aid policy which was limited - due to the poor aid budget and the fragmented composition of the total ODA - to isolated projects mainly implemented by NGOs by technical or/and consultants. The assessment of Austrian EU accession by development experts was ambivalent. Big international, humanitarian NGOs (i.e. Red Cross, Caritas, Care etc.) were in favour of Austrian EU accession because of the option of having access to European budget lines and of co-financing projects and programmes. Small NGOs were scared about the difficult and complex modalities of applying for EC funds. Development Assistance Committee $(\mathrm{DAC})^{\mathrm{I}}$ and EU assessments of the state of Austrian development policy were generally negative (Hödl, 20I3). Assessing the implications of the Austrian EC accession on Austrian development policy, Liebmann concluded that we would observe a lot of different, positive impacts on Austrian trade, economic and foreign policy and of course on development cooperation. Politicians argued that the low official development assistance (ODA) contribution of Austria would automatically increase because of the contributions to EC budget and the European Development Fund (EDF). Liebmann worried that a reallocation of bilateral ODA to the EC budget would be the loss of the Austrian development cooperation identity (Liebmann 1993, I26). The most important effects on Austrian development policy had been expected in financial and administrative terms, also because no differences in programming between Austria and the EC existed (Michael-Misak 1992, I05).

For Austrian development policy the main legal document is the Federal Act on Development Cooperation (Republik Österreich 2002, amended 2003), which provides the following definition of development policy: development co-operation shall comprise any measure by the Federal Government that aims at promoting the sustainable economic and social development of developing countries or preventing any impairment of that development.

I The Development Assistance Committee (DAC) is one of the key forums in which the major bilateral donors work together to increase the effectiveness of their common efforts to support sustainable development. 
It sets out three objectives of development policy: (i) combating poverty by promoting economic and social development; (ii) ensuring peace and security by promoting democracy, rule of law, human rights and good governance; (iii) preserving the environment and protecting natural resources that form the basis for sustainable development. It also sets out the four principles of development policy: (i) consider the aims of partner country governments and populations; (ii) give special regard to culture and the appropriate use of technology for each social environment; (iii) gender equality; (iv) needs of children and people with disabilities (Republik Österreich 2002; 2003).

The common understanding of development policy of the Austrian Government is still limited to aid and humanitarian activities. Despite the inclusion of policy coherence for development in the developmental programs and strategies the goals and principles of the federal act apply only to the programme of the development agency (ADA). Although the Ministry for Europe, Integration and Foreign Affairs (BMEIA) emphasises that development policy is a common task of the whole government, activities of other ministries in developing countries, which can be summarized within the ODA statistics are not following the principles of the federal act. Therefore the Austrian development policy is outsourced to one department of the BMEIA, without the legal power to implement a common Austrian development policy.

\section{EU development policy and EU member states development policy}

Understanding the EU role in the foreign policy of member states is an important focus of much academic work. Given that small states constitute a majority of states within the EU and thus their influence and actions are important (Panke 2010; Wivel/Steinmetz 2010; Nasra 20II). As the introduction states the EU treaties grant an equal legal status to all member states. Research has also focused on small states as donors (Lundsgaarde 2012). Austria can thus be characterised as 'small' in terms of both foreign policy and aid policy (Braun 2010; Alecu de Flers 2012).

Europeanization in its basic form relates to the impact on EU membership on domestic political actors and structures (the so-called downloading), although it can also refer to the impact of member states on the EU level (uploading). We use the definition offered by Moumoutzis (2011, 6I2): Europeanization is defined as 'a process of incorporation in the logic of domestic discourse, political structures and public policies of formal and informal rules, procedures, policy paradigms, styles, "ways of doing things" and shared beliefs and norms that are first defined in the EU policy processes'. In foreign policy terms, the research highlights the weakness of the acquis and therefore highlights the role played by socialization (Tonra 200I; Alecu de Flers/Müller 2012, I5, Wong 2007). The concept was specifically applied to Austrian foreign policy by Alecu de Flers (2OI2, I2I-I22) who showed that "participation in the CFSP can be understood as [having] been based on cost/benefit analyses and the maximization of utilities'.

Development policy is often over-looked in both general and EU foreign policy discussions (Orbie/Lightfoot 2016), but numerous studies show that development assistance is traditionally considered part of a state's foreign policy toolkit (Lancaster 2007; van der Veen 20II). EU Development Cooperation Policy in general was set out in Articles Izou-x of the EC Treaty. The main changes introduced by Lisbon were to provide a specific legal basis for humanitarian aid (TFEU 212-213), whilst development cooperation is now included in articles TFEU 2082II. Article 4 of the TFEU clarifies that development is a shared competence between the Union and the MS, but in contrast to other shared competences such as internal market, agriculture and consumer protection (TFEU 4.2 ), it adds explicitly that "the exercise of that competence shall not result in Member States being prevented from exercising theirs' (TFEU 4.4). EU and MS legislation could develop 'side by side' without affecting each other. There is also an explicit commitment to mutual complementarity between the EU and the MS, implying that neither takes precedence over the other (Broberg 2OII, 545). Therefore, the scope of EU development policy acquis tends to form a body of 'soft law' instruments that are not binding, 'but rest solely on their moral force' (Carbone 2007, 50). In the case of soft law the power of the EU over member states is limited and as such the Commission must rely on persuasion and socialization strategies in order to ensure compliance among member states. There are little or no formal mechanisms to ensure compliance and in any case the acquis in this field is 'soft', or political rather than legal (Grimm et al. 20I2, 7). We therefore argue that the socialization model is applicable in this case. To show this we explore both possible uploading and downloading.

\section{The bottom-up dimension of Europeanization - Austria's influence on EU development policy}

Austria can be seen as a fence sitter in EU development policy, as we are going to show. It tends to react to EU level policies. There has been some attempt to influence policy towards western Balkans, a key strategic interest of Austria's but only in conjunction with other states (Bechev 2006). To this end Austria has forged alliances to try and promote important objectives through forg- 
ing strategic partnerships/alliances with other member states/EU actors (Alecu de Flers 2OI2). It tends to follow Germany and other big states (Pospisil/Khittel 2010, I30). Austria has developed some concentration in security/conflict prevention, explicitly linked to development policy (Pospisil/Khittel 20I0).

During the Austrian presidency of the EU in 2006, Austria added the energy-development interface to the EU agenda. The major contribution was to organise conferences and encourage more work among members on sustainable development (OECD 2009). In line with the Paris Declaration and the Aid Effectiveness discourse Austria emphasised during the presidency the creation of a development cooperation administration in the new member states in order to be able to deliver more effective aid (BMaA 2006, 6I). Austria has also been very active in promoting the European perspective for the Western Balkan states, which was one of key priorities for its presidency in 2006 (Pomorska 20I2). It has brought the Balkans back on the agenda, in particular through raising the issue of security co-operation (O'Brennan 2OI4). Despite the relatively low public support for further enlargement (29\%), with the support of Hungary and Slovenia, it secured a so-called 'Salzburg Declaration' on II March 2006, mentioning the future membership of Serbia, Montenegro, Macedonia, Albania and Bosnia and Herzegovina (Pollak/Puntscher Riekmann 2007, II). The document was later endorsed by the European Council. Apart from this foreign policy initiative both Austrian presidencies were not characterised by strong developmental initiatives in terms of global development. Overall the discussion of Austrian influence over EU agenda reflects the argument that development policy is a 'weak sector' in Austria.

\section{The top-down dimension of Europeanization}

The limited literature on Austrian development policy highlights the pressure from the EU on Austria to ensure its development policy conformed to EU norms and priorities (Hödl 20I3, 274). Therefore we see clear potential for top-down mode of Europeanization. If we examine key aspects of the acquis in the field of development policy we can see EU influence, albeit with some caveats. On issues such as ODA untying aid and aid effectiveness we see shallow Europeanization in the case of Austria. From a developmental perspective the question raised is whether the specific Austrian profit of the EU membership - in financial terms and in political terms - is reflected in the Austrian development policy and development cooperation. To analyse the shifts in Austrian policy and in development cooperation since 1995 we analyse three different aspects: the ODA quantity in relation to the DAC and the DAC EU Member Country- average; the administration structure; and the aid effectiveness agenda.

\subsection{Official development assistance - ODA}

A key element of the soft acquis is the decision of the European Council in Barcelona 2002 (Council of the EU 2002) to increase ODA of the EU-I5 states to the target of $0,7 \%$ GNI by 2015 . To meet the target demands an annual ODA budgetary plan, which addresses goals and objectives in the future. Taking into consideration that the budget reflects policy, looking at the ODA flows show how policy decisions were translated into aid activities and how seriously EU Council decisions are implemented by the Austrian government.

Graph 1: Official development assistance (ODA) of Austria in m US \$ 1990 - 2014

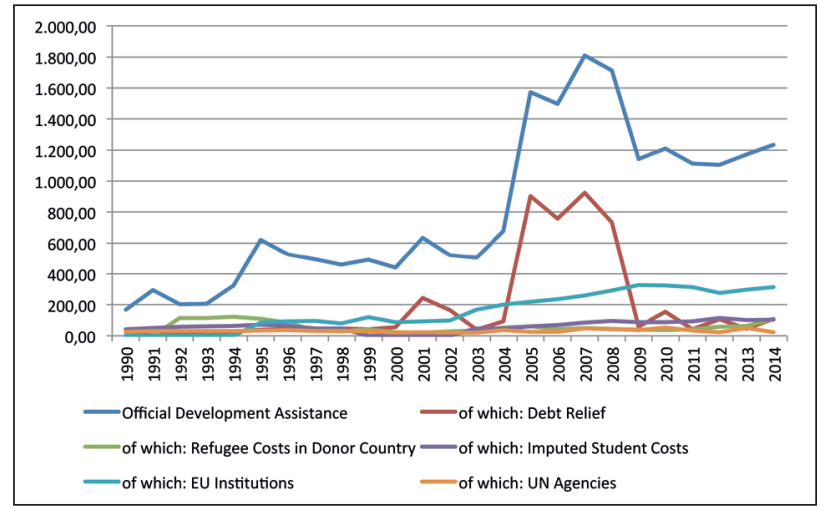

Source: based on DAC Stat online

Graph I shows that ODA increased in 1995 significantly from $323 \mathrm{~m}$ US\$ (1990) to $620 \mathrm{~m}$ US\$. This increase is based on additional contributions to EC budget and EFF (84 mill US\$). In reality the increase was not as big as the data show because due to a revision of the data between 1990 and 2000. After 2000 the total ODA dropped again to $440 \mathrm{~m}$ US\$. If you take into consideration the amount for the EU budget and the EFF ( $87 \mathrm{~m} \mathrm{US \$ )} \mathrm{and}$ increased debt reduction there has been no additional increase since 1994. Between 2001 and 2008 there are several peeks in the ODA data $(2005,2007,2008)$ but these peeks in Austrian ODA performance can be explained by the reporting of debt reduction as ODA, which although in accordance with the DAC reporting rules does help to boost national ODA statistics. The EU ODA-contributions are calculated as a part of the overall EU contribution of an EU member and are reported by the member country. Therefore this is an obligatory contribution linked to the economic situation of a country and not a grant on a voluntary basis i.e. it forms a sort of membership fee. Therefore this linear increase of the EU contributions shows the unintentional Europeanization 
of the Austrian development cooperation because the amount spent on EU institutions far exceeds the money spent on national programmes.

Graph 2: ODA comparison of DAC EU-members average of Austria, Finland, and Ireland in \% of GNI 1990 - 2014

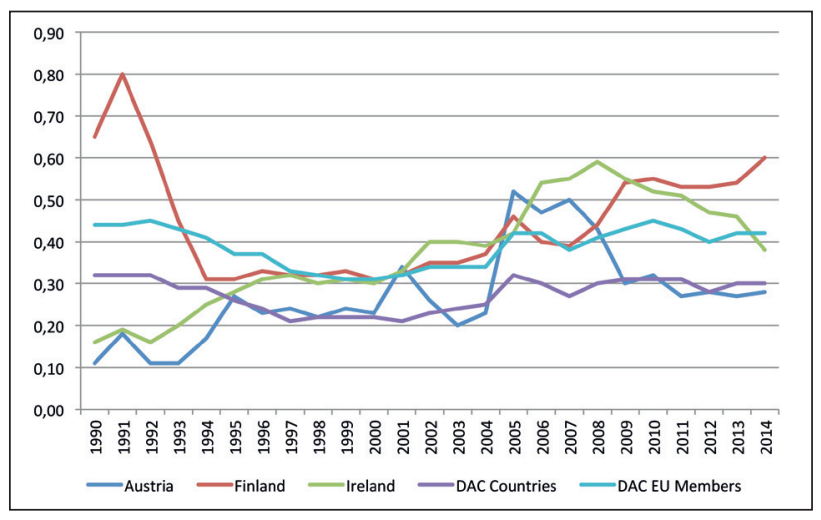

Source: based on DAC Stat online

Comparing the quantity of ODA of Austria with the average of the DAC EU-Member Countries the graph shows that Austria started in 1995 with $0,27 \%$ of GNI as ODA and has reached in 2014 with $0,28 \%$ more or less the same ODA quota than I9 years before. The distance between the lines of Austria and the DAC EU-Member Countries has increased since Austrian EU accession. Compared with Finland - one of the other new EU member states in 1995 - there is more a linear development up to $0,60 \%$ of GNI as ODA in 20I4, despite of financial crises in 2008. Austria therefore did not follow the general trend to increase ODA post 200o. Due to the composition of the Austrian ODA (i.e. high amounts of debt reduction, costs for asylum seekers, imputed student costs and low core budgets for programmable aid) ODA is too volatile to be accordance with the strategy of the

Graph 3: Core budget for programmes and projects between 1990 and 2014 in $\mathrm{m} €$

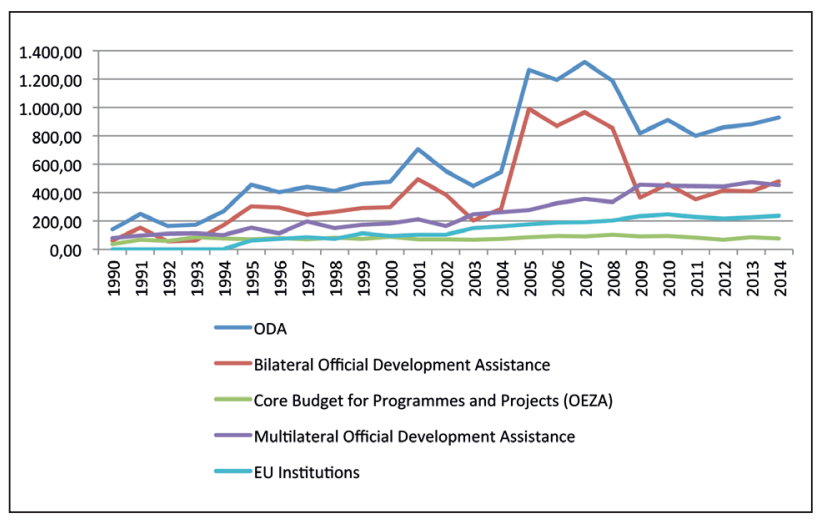

Source: DAC Stat online, own calculations
EU Council. In quantitative terms, Austria even lags far behind Ireland, which started in 1995 on a similar ODA level than Austria in 1995 although Ireland cut their ODA because of the finance crisis in 2008.

Whilst EU membership has not lead to an increase of ODA, EU membership did impact upon the distribution of development spending with almost four times more of the budget spent on EU development cooperation than on Austrian development cooperation.

Austria remains part of a large middle group of countries labeled fence sitters without a prospect to reach the $0,7 \%$ target. Interestingly Austria failed to sign up to this long term target in 2002 (Carbone 2007, 74). Thus, after ten years of benchmarking, monitoring and peer pressurizing (socialization), it is hard to find any evidence of Europeanization. Carbone argues that Austria can be increasingly grouped with southern states when it comes to development policy (Carbone 2007, 42). We agree with the overall conclusion but argue that we must look beyond the budget cuts. Rather we need to focus on the extremely low core aid budget. Austria is not providing aid to priority countries at levels consistent with those of similarly prosperous EU countries (e.g. Ireland, Sweden, Belgium, and Denmark), undermining its profile among donors and in national policy dialogue (DAC 2009).

Domestic politics is a key element in understanding decisions related to aid policy (Lundsgaarde 2013). According to DAC peer review the Austrian Government therefore has public support for meeting its EU aid commitments. Yet, according to Austrian NGOs and opinion leaders, 'strong individual solidarity in Austria does not translate into solidarity at the political level' (DAC 2009). Indeed Hödl (2013) argues that development aid is a marginalised subject within the political debate. Although Austrian developmental NGOs actively support and lobby their politicians for more aid in public debates, they are also highly reliant on the Austrian state for funding. In addition, the media does not give development issues a high profile (Hödl 20I3, 276). Hödl (2013) shows that there is no dissent between the main parties on the rhetorical commitment to the $0.7 \%$ ODA target. However, successive governments - paralyzed by the right wing party - persist in announcements and commitments without ensuring budgetary means. Public opinion and NGO positions are reinforced by a lack of pressure from the private sector. SMEs are seen not to be that interested in overseas export markets (with the exception of SE Europe) plus there is a general lack of transnational corporations. Both factors according to Hödl (2OI3) help reinforce the lack of pressure on the government.

Beyond the international pressure on defaulting donors by international stakeholders (i.e. DAC) by naming and shaming does not work anymore. The bad 
ODA performance of Austria has no news value at all, therefore the annual ranking of donors is of no specific media interest, as long as Austria is not the worst culprit. Public relation departments of the BMEIA and ADA are providing success stories and new announcements and commitments in order to create a positive public opinion. As long as the marginalisation of development policy does not have any national or international political or economic consequences there is no need for Austrian politicians to increase ODA efforts. With reference to many other European countries, which have not fulfilled the ODA target Austria even hides behind the EU and argues that we - as member of the EU - belong to the biggest donor community of international stakeholders.

Despite the general weakness of its aid policy, Austria had held a positive image amongst recipient states. It was seen to be a trusted donor, in part due to the foreign policy position of neutrality (Pospisil/Khittel 2010), 'an alliance-free' one (Hauser 2006, 2II). Taking into consideration the positive image Austria had amongst recipient countries prior to accession (Pospisil/Khittel 20IO), the fact that political rhetoric were not accompanied by financial means and support has jeopardised this image. Austria still benefits from its neutrality status, but since 1995 this argument is not as strong as during the cold war, because many recipient countries do not need a facilitator any longer.

\subsection{The administration of development policy and development cooperation}

There are several institutional models for organizing a country's international development policy. Lancaster $(2007,19)$ argues that aid fragmentation in government equals weak development purpose in government aid programmes. This weakness is visible in Austrian development policy. The transfer of the aid management from the Federal Chancellery to the Ministry of Foreign Affairs (MFA) in 1985 was introduced as a political upgrading because a department dealing with development was established in the MFA for the first time. It was argued that the incorporation of aid in the MFA as a part of Foreign Policy and with an own department gives aid more importance and visibility within foreign policy (Höll I986, I48). One change that is important is the change in responsibility within the MFA. From 1995, the directorate was managed by a Secretary of State, but since 2000, it is now under the direct authority of the Federal Minister for Foreign Affairs (Obrovsky 2005). Despite these frequent changes during the past decades, most of the staff (experts, civil servants, and even top- and middletier diplomats) remained in place. This explains a certain continuity of the priorities of the co-operation programme and the priority countries, without large-scale changes taking place every time political responsibility was transferred.

Taking into consideration the fact that the interest of the conservative party ÖVP in development cooperation was more driven by the interest of linking development cooperation with Austrian economic interests it is not surprising that the Austrian Development Agency (ADA) was established in 2004 during the Schüssel II government. The outsourcing of the management of development cooperation to a private company which is held by the MFA was in line with the general public administration reform in order to reduce administration costs and to organise management activities more effectively. Despite some general critique of the neoliberal concept of outsourcing of public administration, the establishment of ADA was significant because it brought together a team of experts who were focussed on aid delivery based on a political commitment in the context of the MDGs. The establishment of ADA is - to a certain extent - the political and structural answer to the decisions of the European Council in Barcelona 2002 to increase ODA in order to fulfil the Millennium Development Goal 8 and to create a professional agency in order to be fit for participate in other instruments and means of development cooperation (Breier/Wenger 2008). The idea to separate development policy - which is still the mandate of the MFA - and the management of the implementation of programmes and projects followed the example of other European donors (i.e. Germany) and was installed in order to be ready to implement the internationally committed $0,7 \%$ of GNI ODA target. Unfortunately the establishment of ADA was not accompanied by the strengthening of the capacity of MFA in order to fulfil the mandate of following the international development policy and deduce specific Austrian policies. Therefore we see a capacities gap between the policy division and the implementing agency (Breier, Wenger 2008).

ADA (2010) sees itself as an actor within the international development community. This includes cooperation with international organisations, other donors and with the European Union. Since the foundation of ADA the fields of cooperation have been expanded from NGO-co-financing (specifically in development education) to implementing EU-funds and programmes in partner countries, which ADA has been eligible to apply for since 2009 (ADA 20IO). Seven programmes of the European Commission are recently implemented by the ADA with a total amount of $6 \mathrm{Im} €(\mathrm{ADA} 2 \mathrm{OI} 4)$. There is one programme for socioeconomic development in Serbia, one programme in Uganda dealing with supply of water and waste water disposal and another programme in Albania dealing with water reform (ADA 20I4). This shows that ADA - due to the continued lack of an increase of the MFA budget and other national public budgets - offered 
successfully their services to EU and other donors (i.e. Swiss, Liechtenstein) to increase the total turnover in order to legitimate a national Austrian aid agency. EU funds are used to underline the experience and specific knowledge of ADA and to keep experts in specific areas.

In terms of division of labour ADA - in accordance with the MFA - has the mandate to negotiate with partner countries, other donors and international organisations what forms of aid and what instruments are effective and who is going to deliver the appropriate cooperation programme. Therefore ADA is - in specific Austrian focus countries - a partner of the EU commission and the other EU donor countries. The main structural problem is that ADA covers only IO\% of the total ODA. That means that the rest of the ODA is not following in detail the principles and guidelines of the development policy. Although the MFA has the mandate to coordinate development policy with other policies, which effect developing countries, PCD instruments are not established to fulfil PCD effectively (Obrovsky/Schlögl 20II; OECD 2015). As the DAC concluded in the Peer Review 2015: 'Austria does not have a clear approach to addressing policy incoherence. This prevents Austria from fully translating its political commitment into practice and actual policy changes' (OECD 2OI5). This issue will be addressed in more detail in the next section.

\subsection{Aid effectiveness?}

A key element of the soft acquis is the aid effectiveness agenda, whereby states commit to ensuring their aid policies are coordinated with and complimentary to those of other donors and their other policy areas are coherent with development aims. In this section we take a range of indicators and examine Austria's performance, such as reducing the number of countries and sectors supported in order to avoid fragmentation. Austria aims to focus on Poverty reduction; Peace and human security; preserving the environment (Devt Act).

Prior to accession we see that Austrian development cooperation focused on 8 focus countries in the global south, yet post accession we see a general shift towards CEE states, the Western Balkans and the Caucuses because of political or/and economic priorities, and because of the need to align with EU priorities. In the case of the South East European Countries we see an alignment of EU and Austrian interests. The geographical split was reflected in the administration of ODA until 2000, when both departments were put together in the Department of Development Cooperation (DDC) within the MFA. This separation raised concerns in the development cooperation community, which were afraid that the cooperation with the South could easily be replaced by the cooperation with eastern countries in accordance with economic interests instead of following the main purpose of the South cooperation poverty reduction. Although the split was resolved in organisation terms, the contradiction between focus countries and real recipient countries, which was the result of the fragmentation and many different aid spending ministries, was not solved until 2013. This was despite DAC criticisms in every peer review. In 2015 DAC still recommended: 'Austria should bring all aid-spending ministries in line with, and make them accountable for, achieving the objectives of the three-year programmes' (DAC 2015, 15).

When ADA was founded in 2004 it was tasked to bring together the different objectives and goals of south and CEEC cooperation. In 2005 the DAC's ODA eligible list of countries was re-written to reflect the fact that many countries of CEES and NIS had become more prosperous or joined the European Union. By that time we see the shift to include South East European states (Albania, Bosnia \& Hercegovina, Croatia, Macedonia, Serbia and Montenegro inclusive Kosovo) in the budget of ADA and started to increase the disbursements to South East Europe. In 2004 Austria started a co-operation with Moldova, and in 2006 the focus had been expanded to the South Caucasus, and especially Georgia and Armenia (BMEIA 2006). A close coordination with the EU neighbourhood program is mentioned in the MFA strategy (BMEIA 2006, 30). It therefore strikes us that the timing was good for reorientation and that Austria's adjustment in line with EU priority was a stroke of political good fortune, although Africa is still the main Focus of ADA (Uganda, II.8m €; Ethiopia, $6.4 \mathrm{~m} €$ and Mozambique $5.8 \mathrm{~m} €)$.

Although country strategies and regional strategies are established by the ADA and the MFA, a whole of government approach is still missing and results based management of aid delivery is far from being implemented. The DAC recommended in the recent Peer Review that 'Austria is encouraged to develop a consistent and coherent approach to development results as well as a system to inform programming decisions and serve accountability needs' (DAC 2015, I9). This shows how far Austria is from the soft law norms set down by the EU and how limited EU power is in the area.

There is also a commitment to making increased use of the budget support modality and increasing recipient ownership. According to the DAC 'some of Austria's stated commitments to the aid effectiveness agenda seem very cautious' (DAC 2009). They highlight two examples: the decision to concentrate aid in fewer countries and the commitment to budget support. In the Austrian perspective Austria already has concentrated their aid (i.e. ADA budget) to fewer countries but in the DAC perspective total ODA recipients are still too many. The commitment to deliver more budget support has not been realised because without a substantial budget increase there is no additional budget available for 
budget support without cutting the budgets for NGOs, humanitarian organisations and other implementing organisations. The DAC has questioned whether the commitment to allocate $10-15 \%$ of ADA's budget as budget support is too low.

We also examine Austria against the aim of untying aid, the policy by which aid provision is not "tied" to the recipient state using the aid money to buy goods and service from the donor country; European Consensus 2006). Austria made good progress in untying its aid, increasing the share of its untied aid from $39 \%$ in 2005 to $68 \%$ in 2009 but this trend turned again and the share of untied aid declined from $58 \%$ in 2010 to $37 \%$ in 2012. Traditionally, the share of Austrian aid that is untied has been boosted by high levels of debt forgiveness which, by convention, is regarded as untied aid. The fact that debt reduction for South Sudan is not yet included ODA reporting influences both the total volume of Austrian ODA as well as the quality in terms of untying. DAC concluded therefore: 'Austria was one of few countries which did not meet the Accra commitment to provide a clear plan for untying a significant share of remaining tied aid' (DAC 2015, 6I). However that still falls along way short of most other EU-I5 donors and puts Austria in with the Southern European states (again). In part this is due to the fragmented nature of Austrian aid system and the weakness of the MFA in the policy sector.

Increasing policy coherence for development) is recognised by the donor community and hence the EU as one of the most important issues to be tackled in order to make aid more effective; OECD DAC states 'Policy coherence for development has grown in significance in Austria since it appeared on the EU agenda in 200I'. The MFA tries to participate in various international networks, including the EU and the OECD, though it lacks capacity in this respect. The European discussion in $200 \mathrm{I}$ about the $3 \mathrm{Cs}$ (co-ordination, collaboration, coherence) was an important moment in Austria's conceptual thinking about policy coherence for development. In 2005, the EU Consensus on Development became an important frame of reference for Austria regarding policy coherence for development. The rolling EU work program requires regular reporting by member states of their progress and record on policy coherence for development. The Austrian three-year program still refers to the $3 \mathrm{Cs}$ when discussing Austria's contribution to EU development policy. $3 \mathrm{C}$ approach is established in papers of security and development - in specific in the strategic guidelines of security and development (BMEIA 2OII) but it is not implemented in all areas, again highlighting the weakness of EU pressure.

Aid Effectiveness is another way to explore the political effort in delivering aid alongside the quantitative commitment. If development co-operation is implemented in a more effective way this shows that the gov- ernment tries to put more emphasis on managing aid. If there is no effort in quantitative terms but a lot of significant effort in effective delivering of aid this shows some budgetary constraints but a general commitment to a European strategy based on at least a Europeanized Management. The European Commission has proposed a number of policy documents and actions to improve aid and development effectiveness at the European level. These documents were agreed by the member states of the EU (Commission 2006). But at the end of the day - in terms of development - money matters. An Europeanized effective aid management without significant financial means remains a lame duck with no perspective to take off. Therefore ADA is ready for delivering aid - without significant financial means their contribution to the EU development cooperation remains negligible.

\section{Conclusion}

Being a donor was imposed upon Austria by EU membership. In terms of development cooperation, like many other policy areas, this is not unusual - the price for EU membership is that a state must adhere to the rules of the game. Austria saw EU development policy as an external framework it had to accept to join the EU. Austria took the economic advantages of the accession to the EU, but, and here we support Gerald Hödl - whilst the EU development policy was 'established together with the DAC certain norms 'it could not prevent a small country like Austria from keeping its ODA efforts at a minimum' (Hödl 20I3). This shows that the EU system of socialization or the international system of naming and shaming with DAC statistics is not working. Austrian political will is limited because - due to the soft law of $\mathrm{EU}$ acquis and the lack of consequences - the repetition of the ODA commitments replaced the implementation. The idea behind our argument is that the decision not to increase the ODA follows a specific political economy, because without any sanctions and consequences there is no need to increase ODA in the future. Austria has to pay increased fees to EU but as a small country Austria is not bound to fulfil international commitments in detail as long as France, Germany and other big players fail. Therefore Austria's multilateral contributions to the EU budget and to the EEF went up but not as a result of political decisions. The EU has established an additional multilateral aid architecture (which is to a certain extent more binding than DAC and UN) but at the end the $\mathrm{EU}$ is not able to force their members to fulfil their commitments, reflecting the shallow nature of the acquis. In our perspective the EU offers a framework to hide, because Austria (and others) can argue that Austria - as a member of the EU - belongs to the biggest donor group to developing world. 
The current Austrian Commissioner Johannes Hahn (Neighbourhood policy and Enlargement) summarized in a press bulletin that 20 years of Austrian membership are a success story (Hahn 2015). This article showed that in regard of development diplomacy this holds true in a European but not in a global perspective. In terms of development cooperation Austria did neither establish an own national approach nor took the European one. Thus we see 'shallow' Europeanization in Austria whereby rhetorical engagement with the $\mathrm{EU}$ acquis is evident but the engagement goes little beyond that. Linking to the framework we see seeking benefits: Austria adapts the political rhetoric without implementing structures and providing financial means. This gives more national political space without too much obligations. Although Austrian politicians committed themselves to the international 0.7\% ODA goal they never put in place solid structures to realise this commitment. In quantitative terms a silent Europeanization took place because Austria delivers much more money to European development instruments than to the ADA budget and bilateral programmes and projects. Without a proper national development programme and a significant ODA performance there are doubts if Austria is recognised as a European donor at all - neither in Europe nor by our partner countries in the global South.

In terms of foreign policy interests Austria squandered the potential development policy and development cooperation offers to position - in specific - a small country like Austria as an important player in the global context. Even if we take into consideration that small countries need to find their niches and deliver specific contributions focussed on small partner countries the foundation of ADA and the focus on the Western Balkan countries was an important step into the right direction but without delivering significant means and a broad political consensus to development policy and foreign policy it is a weak political performance that undermines Austrian credibility as well on an European level as in partner countries in the global South. Overall, we argue that there has only been shallow Europeanization in the context of Austrian development policy. Given the closeness of development policy to foreign policy goals in the Austrian case this conclusion is perhaps not that surprising. However, we also show that Austria is unable to upload its foreign policy preferences without the support of larger member states. Austrian aid lacks the political will to push it in the direction of the more global direction called for by the EU acquis and to a large extent, as it supports the national interest, this situation is unlikely to change in the near future.

\section{Literature}

Alecu de Flers, Nicole (2012). EU foreign policy and the Europeanization of neutral states: comparing Irish and Austrian foreign policy, London.

Alecu de Flers, Nicole/Patrick Müller (2012). Dimensions and Mechanisms of the Europeanization of Member State Foreign Policy: State of the Art and New Research Agendas, in: Journal of European Integration, Vol. 34(I), 19-35.

Austrian Development Agency (ADA) (2010). Unternehmenskonzept 20IO, Vienna.

AustrianDevelopmentAgency (ADA)(2014).Geschäftsbericht 20I3, Wien. Internet: http://www.entwicklung.at/ uploads/media/ada_Geschaeftsbericht_2OI3_or.pdf (accessed on: 13.03.2016).

Bechev, Dimitar (2006). Carrots, sticks and norms: the EU and regional cooperation in Southeast Europe, in: Journal of Southern Europe and the Balkans, Vol. 8(I), 27-43.

Breier, Horst/Bernhard Wenger (2008). Evaluierung der Tätigkeit der Austrian Development Agency (ADA). Schlussbericht, Bonn/Zürich. Internet: http://www.entwicklung.at/uploads/media/ADA_ Evaluierungsbericht_2008.pdf (accessed: 13.3.2016).

Broberg, Morton. (20II). What is the Direction for the EU's Development Cooperation after Lisbon? A Legal Examination, in: European Foreign Affairs Review, Vol. 16(4), 539-557.

Bundeskanzleramt (1993). Dreijahresprogramm der österreichischen Entwicklungshilfe 1994 bis 1996 (Fortschreibung), Vienna.

Bundesministerium für auswärtige Angelegenheiten $(B M a A)$ (2006). Dreijahresprogramm der österreichischen Entwicklungspolitik 2006-2008, Vienna.

Bundesministerium für europäische und internationale Angelegenheiten (BMEIA) (2009). Strategischer Leitfaden Umwelt und Entwicklung der österreichischen Entwicklungspolitik, Vienna.

Bundesministerium für europäische und internationale Angelegenheiten (BMEIA) (20IO). Dreijahresprogramm der österreichischen Entwicklungspolitik 20IO 2012, Vienna.

Bundesministerium für europäische und internationale Angelegenheiten (BMEIA) (2OII). Strategischer Leitfaden Sicherheit und Entwicklung der österreichischen Entwicklungspolitik, Vienna.

Bundesministerium für europäische und internationale Angelegenheiten (BMEIA) (20I3). Dreijahresprogramm der österreichischen Entwicklungspolitik 2013 -2015, Vienna.

Carbone, Maurizio (2007). The European Union and international development: the politics of foreign aid, London. 
Commission of the EU (2006). EU Aid: Delivering more, better and faster. COM 2006/87, Brussels. 02.03.2006 $\operatorname{COM}(2006) 87$ final.

Council of the European Union (2002). Presidency Conclusions, SNIoo/I/O2REVI, Barcelona, I5.16.03.2002.

European Consensus (2006). Joint declaration by the Council and the representatives of the governments of the Member States meeting within the Council, the European Parliament and the Commission on the development policy of the European Union entitled The European Consensus. Official Journal C 46 of 24 February.

Grimm, Sven/Davina Makhan/Stefan Gänzle (eds.) (2012). The European Union and Global Development - An Enlightened Superpower in the Making?, London.

Hahn, Johannes (2015). Presseaussendung der Vertretung der EU-Kommission in Österreich vom I.I.2O15. Internet: http://www.ots.at/presseaussendung/OTS 20150IOI_OTSOO29/20-jahre-eu-mitgliedschaftoesterreichs-eine-erfolgsgeschichte-die-esdurch-aktives-engagement-fortzusetzen-und-zuvertiefen-gilt (accessed: 13.03.2016).

Hödl, Gerald (2013). Chronic Underachievement. Austria's Development Aid in Historical Perspective, in: Thorsten B. Olesen/Helge Pharo (eds.), Saints and Sinners. Official Development Aid and Its Dynamics in a Historical and Comparative Perspective, 255278, Oslo.

Höll, Otmar (1986). Österreichische Entwicklungshilfe 1970-1983: Kritische Analyse und internationaler Vergleich, Vienna.

Lancaster, Carol (2007). Foreign Aid: Diplomacy, Development, Domestic Politics, Chicago.

Liebmann, Andreas (1993). Leitfaden zur europäischen Entwicklungszusammenarbeit. Schriftenreihe Europa des Bundeskanzleramtes Band 3, Vienna.

Lundsgaarde, Erik (2012). The domestic politics of foreign aid, Abingdon.

Michal-Misak, Silvia (1992). Auch keine Patentlösung. Die EntwicklungspolitikderEuropäischenGemeinschaft, in: Arbeitsgemeinschaft Entwicklungszusammenarbeit (Hg.) (1992), Soll und Haben Konturen der österreichischen Entwicklungspolitik I, Vienna.

Moumoutzis, Kyriakos (201I). Still Fashionable Yet Useless? Addressing Problems with Research on the Europeanization of Foreign Policy, in: Journal of Common Market Studies, Vol. 49(3), 607-629.

Nasra, Skander (2OII). Governance in EU foreign policy: exploring small state influence, in: Journal of European Public Policy, Vol. I8(2), I64-I80.

O'Brennan, John (2014). The EU and the Western Balkans: Stabilization and Europeanization through Enlargement?, Abingdon.
Obrovsky, Michael (1993). Struktur Anpassung. Zu den politischen und administrative Rahmenbedingungen der österreichischen Entwicklungszusammenarbeit, in: AGEZ (Hg.), Zusammen Arbeit. Konturen der österreichischen Entwicklungspolitik 2, Linz/ Vienna.

Obrovsky, Michael (2005). Austrian Aid Policy, in: Paul Hoebink/Olav Stokke (eds.): Perspectives on European Development Co-operation, London.

Obrovsky, Michael/Lukas Schlögl (20II). Politikkohärenz durch Kohärenzpolitik! Bedingungen für Policy Coherence for Development in Österreich, Wien: ÖFSE, 2OII, Vienna. Internet: http://www.oefse. at/fileadmin/content/Downloads/Publikationen/ Editionen/EditionI7.pdf (accessed: 13.03.2016).

Obrovsky, Michael (2012). Die öffentliche Entwicklungszusammenarbeit - Official development Assistance. In: Österreichische Forschungsstiftung für Internationale Entwicklung. Österreichische Entwicklungspolitik. Analysen, Berichte, Informationen. Die Zukunft der österreichischen Entwicklungspolitik. Vienna.

OECD (1993). Aid Review 1992/93 Report by the secretariat and questions for the Review of Austria, Paris.

OECD (2009). OECD Development Assistance Committee Peer Review Austria, Paris.

OECD (2015). OECD Development Co-operation Peer Reviews Austria 2015, Paris.

Orbie, Jan (2012). The EU as an actor in development: Just another donor, European norm maker, or eclipsed by superpower temptations?, in: Sven Grimm/Davina Makhan/Stefan Gänzle (eds.), The European Union and Global Development - An Enlightened Superpower in the Making?, London, I7-36.

Orbie, Jan/Simon Lightfoot (2016). Development: Shallow Europeanization?, in: Amelia Hadfield/Ian Manners/ Richard G. Whitman (eds.): Foreign Policies of EU Member States, London.

Österreichische Forschungsstiftung für Entwicklungshilfe ÖFSE (Hg.) (1997). Österreichische Entwicklungspolitik 1996, Berichte, Analysen, Informationen, Vienna.

Panke, Diana (2010). Small States in the European Union: Coping with Structural Disadvantages, London.

Pollak, Johannes/Sonja Puntscher Riekmann (2007). The Austrian Presidency: Pragmatic Management, in: Journal of Common Market Studies, Vol. 45(I), 7-I6.

Pospisil, Jan/Stefan Khittel (2010). Is there an advantage in being small?, in: Paul Hoebink (ed.): European Development Cooperation - In Between the Local and the Global, Amsterdam: Amsterdam University Press, I25-I44.

Pomorska, Karolina (2012). Poland: Learning the Brussels Game, in: Christopher Hill/Reuben Wong (eds.): National and European Foreign Policies: Towards Europeanization, London, I67-I88. 
Rechnungshof (2009). Entwicklungszusammenarbeit im BMeiA und in der Austrian Development Agency. http://www.rechnungshof.gv.at/fileadmin/ downloads/2009/berichte/teilberichte/bund/ bund_2009_II/Bund_2009_II_I.pdf (accessed on: 13.03.2016).

Republik Österreich (2002). 49. Bundesgesetz: Entwicklungszusammenarbeitsgesetz, EZA-G und Änderung des Urlaubsgesetzes, BGBl. I - BGBl. I from 29 March 2002.

Republik Österreich (2003). 65. Bundesgesetz: EZA-GesetzNovelle 2003, BGBl. I - BGBl. I from I4 August 2003.

Schuster, Nadja/Jutta Kepplinger/Ingrid Pranger/Inge Jäger (2008). Politikkohärenz im Interesse der Entwicklung, Ein Leitfaden zu Policy Coherence for Development. Parlamentarischer Nord Süd Dialog, Vienna.

Tonra, Ben (200I). The Europeanisation of National Foreign Policy: Dutch, Danish and Irish Foreign Policy in the European Union, Aldershot.

Van der Veen, Mauritis (20II). Ideas, Interests, and Foreign Aid, Cambridge.

Wivel, Anders/Robert Steinmetz (2010). Small States in Europe, Farnham.

Wong, Reuben (2007). Foreign Policy, in: Paolo Graziano/ Maarten Vink (eds.), Europeanization: New Research Agendas, Basingstoke, 32 I-336.

\section{Authors}

Dr. Michael Obrovsky is deputy director of the Austrian Foundation of Development Research - ÖFSE. He gives lectures at the Institute of International Development studies at the University of Vienna and at the DanubeUniversity Krems. His Research areas are: development policy, financing for development, civil society and development.

Dr. Simon Lightfoot is a Senior Lecturer in European Politics at the University of Leeds, UK. His research areas are development policy, especially in Central and Eastern Europe and at the EU level. He is also co-convenor of the EADI Working Group on the Development Aid of the Non-DAC Donors. 
